\title{
Effects of chronic environmental cold on growth, health, and select metabolic and immunologic responses of preruminant calves ${ }^{1}$
}

\author{
B. J. Nonnecke, ${ }^{* 2}$ M. R. Foote,$\dagger^{3}$ B. L. Miller, $\ddagger$ M. Fowler, $\ddagger$ T. E. Johnson, $\ddagger$ and R. L. Horst $t^{* 4}$ \\ *USDA, ARS, National Animal Disease Center, Periparturient Diseases of Cattle Research Unit, PO Box 70, Ames, IA 50010 \\ †Department of Animal Science, lowa State University, Ames 50010 \\ fLand O'Lakes Inc., 1025-190th St., PO Box 65, Webster City, IA 50595
}

\begin{abstract}
The physiological response of the preruminant calf to sustained exposure to moderate cold has not been studied extensively. Effects of cold on growth performance and health of preruminant calves as well as functional measures of energy metabolism, fat-soluble vitamin, and immune responsiveness were evaluated in the present study. Calves, 3 to $10 \mathrm{~d}$ of age, were assigned randomly to cold $(\mathrm{n}=14)$ or warm $(\mathrm{n}=15)$ indoor environments. Temperatures in the cold environment averaged $4.7^{\circ} \mathrm{C}$ during the study. Frequent wetting of the environment and the calves was used to augment effects of the cold environment. Temperatures in the warm environment averaged $15.5^{\circ} \mathrm{C}$ during the study. There was no attempt to increase the humidity in the warm environment. Preventative medications or vaccinations that might influence disease resistance were not administered. Nonmedicated milk replacer (20\% crude protein and $20 \%$ fat fed at $0.45 \mathrm{~kg} / \mathrm{d}$ ) and a nonmedicated starter grain fed ad libitum were fed to all calves. Relative humidity was, on average, almost $10 \%$ higher in the cold environment. Warm-environment calves were moderately healthier (i.e., lower respiratory scores) and required less antibiotics. Scour scores, days scouring, and electrolyte costs, however, were unaffected by environmental temperature. Growth rates were comparable in warm and cold environments, although coldenvironment calves consumed more starter grain and had lower blood glucose and higher blood nonesterified fatty acid concentrations. The nonesterified fatty acid and glucose values for cold-stressed calves, however, did not differ sufficiently from normal values to categorize
\end{abstract}

Received June 25, 2009.

Accepted September 2, 2009.

${ }^{1}$ Names are necessary to report factually on available data; however, the USDA neither guarantees no warrants the standard of the product, and the use of the name by the USDA implies no approval of the product to the exclusion of the other that may also be suitable.

${ }^{2}$ Corresponding author: brian.nonnecke@ars.usda.gov

${ }^{3}$ Current address: Department of Animal Science, Cornell University, Ithaca, NY 14853.

${ }^{4}$ Current address: Heartland Assays Inc., Ames, IA 50010. these calves as being in a state of negative-energy balance. Levels of fat-soluble vitamin, antibody, tumor necrosis factor- $\alpha$, and haptoglobin were unaffected by sustained exposure to moderate cold. These results support the contention that successful adaptation of the dairy calf to cold is dependent upon the availability of adequate nutrition.

Key words: preruminant calf, cold stress, neonatal immunity, calf physiology

\section{INTRODUCTION}

Infectious diseases of calves, especially diarrheal and respiratory diseases, are associated with significant economic losses to the US dairy cattle industry. The mortality rate for preweaned dairy calves is approximately 8 to $11 \%$ and the morbidity rate is approximately $37 \%$ (National Animal Health Monitoring Service, 2002). Infectious diseases of the calf also affect human health and food safety through preharvest contamination and zoonotic transmission. Agents causing these diseases can be transmitted to humans through direct contact or by contamination of food and water supplies.

There is a dearth of information describing the functional competency of the immune system of the neonatal calf and how management-related factors (i.e., nutrition, environmental conditions) influence the immune responsiveness and, ultimately, infectious disease resistance. In the northern United States, calves born in the late winter and early spring often experience sustained periods of cold during the first weeks of life. A recent study by Godden et al. (2005) documents the negative effects of winter calving on dairy calf health. Of the 438 calves evaluated, the morbidity rate of calves born in the winter was $52 \%$ compared with $13 \%$ for calves born in the summer. Similarly, calf mortality was $21 \%$ in the winter and $3 \%$ in the summer. Several studies suggest that reduced temperature alone is not the sole contributor to increased morbidity and mortality during winter calving. In California, calf mortality was shown to be highest in mid-winter and mid-summer, although winter losses are 1.26 times those in the summer. Losses 
in winter were associated with cold, wet, and windy weather, whereas losses in the summer were associated with hot, dry weather (Martin et al., 1975). A Danish study (Blom et al., 1984) demonstrated an increased incidence of pneumonia in calves given a milk substitute, hay, and concentrates, when ambient temperature was less than $10^{\circ} \mathrm{C}$ and relative humidity exceeded $85 \%$, suggesting that low temperature in conjunction with elevated humidity decreases calf health.

Effects of environmental cold on specific aspects of the immune and stress responses have been examined in other species. Relatively brief exposure (i.e., 5 d) of pigs to cold increases baseline concentrations of the stress-related hormones $\mathrm{ACTH}$ and cortisol and elevates proinflammatory cytokines [i.e., IL-1 $\beta$, IL-6, and tumor necrosis factor ( $\mathbf{T N F})-\alpha]$ in the liver and spleen (Frank et al., 2003). A recent study demonstrated that cold stress, regardless of duration, influences cytokine gene expression (Hangalapura et al., 2005). In

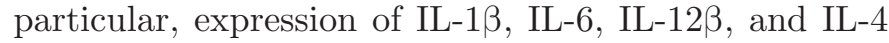
mRNA in peripheral blood leukocytes was enhanced, suggesting that cold stress stimulates both the innate and adaptive arms of the chicken's immune system. In cold-stressed rats chronically infected with Toxoplasma gondii, responses of splenic lymphocytes to antigens derived from this pathogen were markedly suppressed (Aviles et al., 2004). Reduced functional capacity of this leukocyte population could lead to reactivation of the latent infection. In mice, bacterial clearance from the lungs following challenge is inhibited by cold stress in conjunction with wet fur (Green and Kass, 1964).

Nutrition is a determinant of immune function, with protein-energy balance influencing cell-mediated immunity, cytokine production, complement system, phagocytic function, and antibody concentrations (Woodward, 1998). Ensuring nutritional sufficiency during periods of cold stress may be difficult in the preruminant calf because maintenance requirements for thermoregulation are increased (Drackley, 2005). In a thermoneutral environment, the calf is not required to elicit specific heat-conserving or heat-dissipating mechanisms to maintain core body temperature (NRC, 2001). The thermoneutral zone of the young calf varies with age, weight, environmental temperature, and other stressors (Schrama et al., 1992, 1993; Scibilia et al., 1987) and ranges from 15 to $25^{\circ} \mathrm{C}$. When the lower critical temperature (LCT; the effective ambient temperature dependent on wind velocity, humidity, and tissue insulation) is reached, a calf must produce more heat (i.e., expend energy) to maintain body temperature. When temperatures fall below the LCT, the energy needed to maintain core body temperature is supplied either by increased energy intake or from increased metabolism of tissue reserves. In the northern states during the winter and early spring, many calves experience degrees of cold-stress necessitating increased dietary energy to limit the negative effects of cold on growth performance and health. Although the beneficial effects of increased nutrition in the form of intensified milk replacers on the immune response capacity and health of calves reared in a thermoneutral environment have not been demonstrated conclusively (Nonnecke et al., 2003; Foote et al., 2007b), intensified feeding programs may support optimal growth and promote infectious disease resistance during periods of sustained cold stress.

The objective of the present study was to evaluate the effects of sustained exposure to moderate cold on the growth performance, health, metabolism, and immune system of milk replacer (MR)-fed dairy calves. In an attempt to mimic typical on-farm calf nutrition programs, calves in warm and cold environments were provided fixed and equal amounts of a $20 \% \mathrm{CP}, 20 \%$ fat MR with starter grain provided ad libitum.

\section{MATERIALS AND METHODS}

\section{Calves and Environmental Treatments}

Animal-related procedures were implemented following institutional guidelines for animal care and use. Twenty-nine Holstein bull calves 3 to $10 \mathrm{~d}$ of age and weighing between 40.8 and $45.4 \mathrm{~kg}$ at the beginning of the study were used. All calves had serum IgG concentrations $\geq 10 \mathrm{~g} / \mathrm{L}$ as determined by ELISA (Nonnecke et al., 2003), indicative of successful acquisition of passive immunity. No preventative medications or vaccinations were administered that might influence disease resistance. Calves were examined for navel infection before the trial and navels were dipped in a $3.5 \%$ iodine solution. The evening before the trial, all calves received electrolytes orally $(0.077 \mathrm{~kg}$ in $1.8 \mathrm{~kg}$ of water). During the 49-d study, all calves were fed nonmedicated MR $(0.45 \mathrm{~kg} / \mathrm{d}, 20 \% \mathrm{CP}$ and $20 \%$ fat; Table 1) and a nonmedicated calf starter (ad libitum, $18 \% \mathrm{CP}$, nonmedicated, Land O'Lakes-Purina Feed, Shoreview, MN) with lasalocid acid. From d 0 to 42 calves were fed MR twice daily and once daily thereafter. Calves were weaned at d 49 .

Calves were assigned randomly to 2 environmental treatments at the beginning of the study and remained in their respective environments until d 49 of the study. They were housed individually on elevated stalls in 2 indoor, ventilated rooms from January to March. Calves reared in the cold (unheated) environment $(\mathrm{n}=$ 14) were exposed to temperatures maintained as close to $1.7^{\circ} \mathrm{C}\left(35^{\circ} \mathrm{F}\right)$ as possible. Wetting of the environment and calves twice daily was used to increase humidity and augment the effects of the cold. Wetting resulted 
Table 1. Composition of milk replacer ${ }^{1}$ fed during the experimental period

\begin{tabular}{lc}
\hline Component & DM analysis \\
\hline CP, \% & $\geq 20$ \\
Crude fat, \% & $\geq 20$ \\
Crude fiber, \% & $\leq 0.15$ \\
Moisture, \% & $\leq 5.0$ \\
Calcium, \% & 0.75 to 1.25 \\
Phosphorus, \% & $\geq 0.70$ \\
Ash, \% & $\leq 13.2$ \\
Added minerals, \% & $\leq 0.05$ \\
Vitamin A (retinyl acetate), IU/kg & $\geq 9,072$ \\
Vitamin $\mathrm{D}_{3}$ (cholecalciferol), IU/kg & $\geq 2,268$ \\
Vitamin E, IU/lb. & $\geq 45.4$ \\
\hline
\end{tabular}

${ }^{1}$ Nonmedicated; manufactured by Land O'Lakes Milk Products Co. (Black River Falls, MN).

in the hair coat being saturated with water. Calves in the warm environment $(\mathrm{n}=15)$ were exposed to temperatures maintained as close to $15.6^{\circ} \mathrm{C}\left(60^{\circ} \mathrm{F}\right)$ as possible. Humidity of the warm environment was not manipulated. High and low temperature and humidity readings in both rooms were recorded manually each day.

Calves were weighed at weekly intervals beginning on $\mathrm{d} 0$ of the trial. The quantities of MR consumed and refused were recorded daily and these values were converted to the amount of dry matter consumed. Similarly, the amount of starter consumed and weigh backs were recorded daily. Calf health was observed at each morning feeding. Body temperatures, scour and respiratory scores, and the type and amount of antibiotics administered were recorded for clinically ill calves. The scoring system has been described previously (Nonnecke et al., 2003). Calves with scour scores $>2$ were given electrolytes orally and were given lactated Ringer's solution parenterally when obviously dehydrated. The amount and frequency of electrolyte administrations were recorded.

All calves were sensitized to ovalbumin (OVA) to evaluate the effects of cold on the adaptive immune response. Calves were vaccinated on $\mathrm{d} 0$ and 35 . The vaccine consisted of crystallized OVA (Grade V, Sigma, St. Louis, MO) dissolved in sterile PBS $(2 \mathrm{mg} / \mathrm{mL})$, diluted 1:1 (vol/vol) in incomplete Freund's adjuvant (MP Biomedicals, Inc., Aurora, OH) and emulsified by sonification (model 250 Sonifier, Branson, Danbury, $\mathrm{CT})$. The vaccine $(4 \mathrm{~mL})$ was administered subcutaneously in the left mid-cervical region.

Serum was collected by jugular venipuncture from each calf at the beginning of the study (prevaccination, $\mathrm{d} 0$ ) and at d 35, 42, and 49. Coagulated (no additive) blood samples were collected into $10-\mathrm{mL}$ vacutainers (Becton Dickinson, Franklin Lakes, NJ). Harvested serum was frozen $\left(-20^{\circ} \mathrm{C}\right)$ until analysis.

\section{Quantification of Glucose, NEFA, and Fat-Soluble Vitamins}

Glucose and NEFA concentrations were determined in serum samples collected on d 0, 35, 42, and d 49 of the experimental period. Samples were collected in the morning before feeding. Serum NEFA concentrations were determined colorimetrically as described previously (Johnson and Peters, 1993), and glucose concentrations were determined colorimetrically using a commercially available kit (BioAssay Systems, Hayward, CA). In both assays, samples from calves in each treatment group were processed simultaneously so that interassay effects would be balanced across treatments. Intraassay coefficient of variation in both assays was $<3 \%$.

Retinol and $R R R$ - $\alpha$-tocopherol concentrations in $\mathrm{d} 0$, 35,42 , and 49 serum samples were analyzed by reversephase HPLC as described previously (Ametaj et al., 2000) using a modification of the method of Kaplan et al. (1987). Serum 25-hydroxyvitamin $\mathrm{D}_{3}\left[\mathbf{2 5}(\mathbf{O H}) \mathbf{D}_{3}\right]$ was quantified by RIA using the methods of Hollis et al. (1993).

\section{Quantification of Antigen-Specific IgG, TNF- $\alpha$, and Haptoglobin}

Antigen (i.e., OVA)-specific $\operatorname{IgG}_{1}$ and $\operatorname{IgG}_{2}$ concentrations in serum samples from d 0, 35, 42, and 49 were determined by capture ELISA as described by Foote et al. (2007a). Optical densities (450 nm) of individual microtiter-plate wells were measured using an ELISA plate reader (Dynatech MR7000, Dynatech Laboratories Inc., Guernsey, Channel Islands, UK). The change in optical density (OD) was calculated by subtracting the OD of wells containing PBS only from the OD of wells containing test samples.

Tumor necrosis factor- $\alpha$ in d $0,35,42$, and 49 samples was measured by capture ELISA as described by Nonnecke et al. (2005). The OD of standards and test samples at 405 and $490 \mathrm{~nm}$ were measured using an ELISA reader (Dynatech Laboratories Inc.). Cytokine concentrations in test sera, evaluated in duplicate, were determined by comparing the absorbance of test samples with the absorbance of standards (serially diluted recombinant bovine $\mathrm{TNF}-\alpha$ ) within a linear curve fit. Results were expressed as mean TNF- $\alpha$ concentrations $(\mathrm{ng} / \mathrm{mL})$ in sera samples.

Haptoglobin concentrations in sera harvested on d $0,35,42$, and 49 were determined using a bovine haptoglobin ELISA (Immunology Consultants Laboratory Inc., Newberg, OR) following the manufacturer's instructions. Haptoglobin standards provided in the kit ranged from 62.5 to $1,000 \mathrm{ng} / \mathrm{mL}$. The OD (450 nm) 

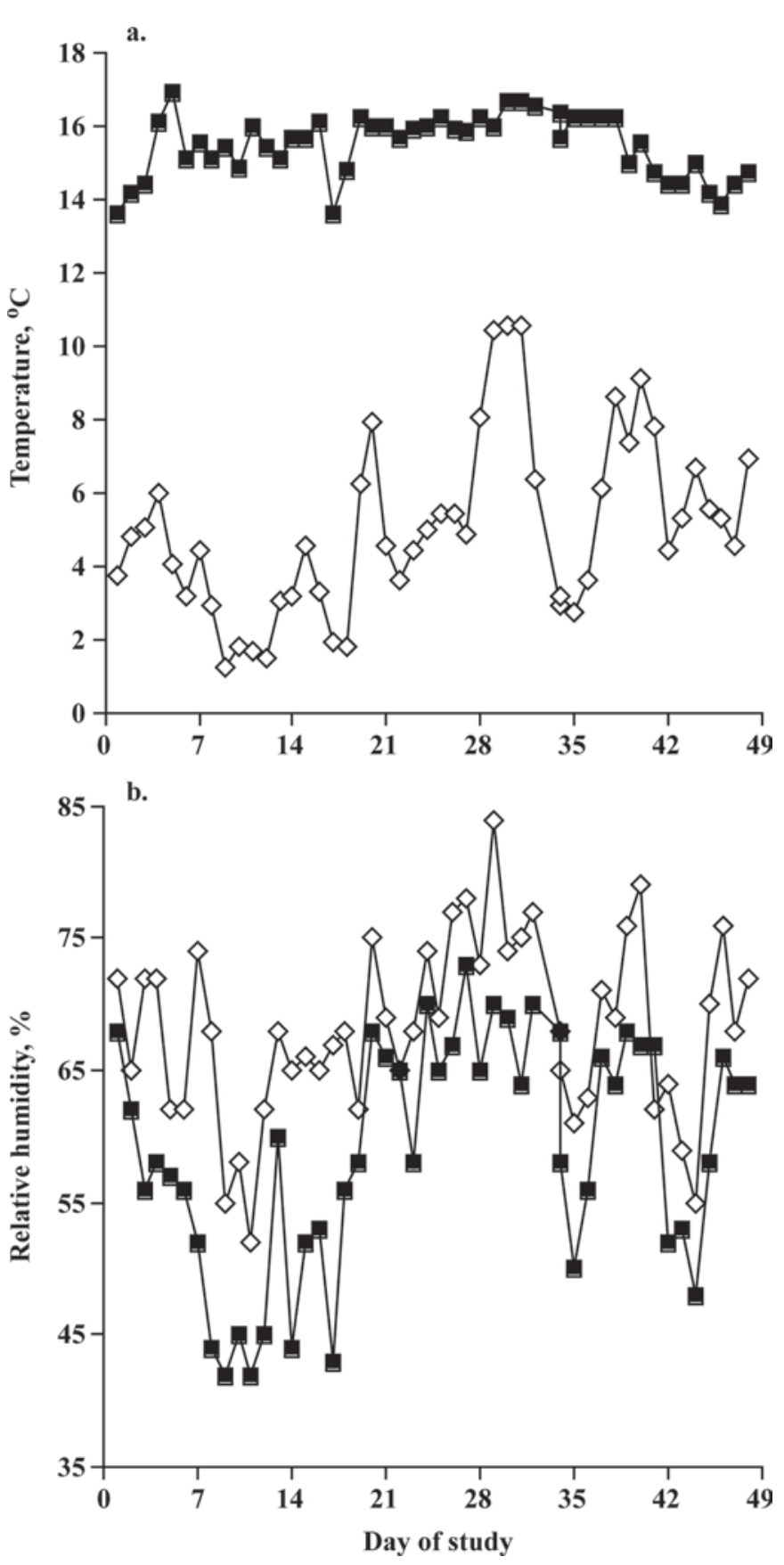

Figure 1. Mean daily temperature (a) and relative humidity (b) in warm $(\mathbf{\square})$ and cold $(\diamond)$ environments housing preruminant calves. Means were derived from high and low temperature and humidity readings recorded during each 24 -h period from d 1 to d 49 of the experimental period.

of test samples and standards was measured using an ELISA plate reader (Dynatech Laboratories Inc.). Haptoglobin concentrations in test sera, evaluated in duplicate, were determined by comparing the absorbance of test samples with that of serially diluted standards within a linear curve fit. These data were corrected for dilution factor to arrive at haptoglobin concentration $(\mu \mathrm{g} / \mathrm{mL})$ in the original sample.

\section{Statistical Analysis}

Data were analyzed as a completely randomized design (JMP, version 5.0, SAS Institute Inc., Cary, NC). Calf served as the experimental unit in the analysis of all data. Body weight; environmental temperature and humidity; serum metabolites (i.e., fat-soluble vitamins); and serum antibody, TNF- $\alpha$, and haptoglobin concentrations were analyzed as a split-plot with repeatedmeasures ANOVA. The model included fixed effects of environmental treatments, time (week of experiment), and the treatment $\times$ time interaction. Calf was included in the model as the random effect. Fisher's protected LSD test was applied when effects $(P \leq 0.05)$ were detected.

\section{RESULTS AND DISCUSSION}

\section{Environmental Conditions}

Daily room temperatures (representing mean of low and high temperatures) in warm and cold environments are shown in Figure 1a. Cold-environment temperatures averaged $4.7^{\circ} \mathrm{C}$ during the study period and ranged from a low of $1.2^{\circ} \mathrm{C}(\mathrm{d} 9)$ to a high of $10.5^{\circ} \mathrm{C}(\mathrm{d} 40)$. Warmenvironment temperatures averaged $15.5^{\circ} \mathrm{C}$, higher $(P<0.0001)$ than the cold-environment temperature $\left(4.7^{\circ} \mathrm{C}\right)$, and ranged from a low of $13.6^{\circ} \mathrm{C}(\mathrm{d} 17)$ to a high of $16.9^{\circ} \mathrm{C}(\mathrm{d} 5)$. The stability of temperatures in the warm environment was because of thermostatically controlled heating. Because the cold environment was not heated, the more pronounced fluctuations of temperatures in the cold environment were attributable to changes in weather from January through March.

Daily room humidities in warm and cold environments are shown in Figure 1b. Relative humidity in the cold environment during the study period averaged $68.2 \%$ and ranged from a low of $52 \%$ (d 11) to a high of $84 \%$ (d 29). Relative humidity in the warm environment averaged 59\% and ranged from $42 \%$ (d 11) to $73 \%$ (d 27). Average humidities in warm and cold environments during the study period were different $(P<0.001)$. This difference was not large; however, regular wetting of the fur of cold environment calves likely increased the physiological effect of the cold. The use of elevated stalls prevented the calves from nesting, which would have reduced the LCT of the calves and their caloric needs (Lago et al., 2006). Although this is a subjective observation, the coats of calves in the cold environment thickened markedly during the first week of the study suggesting a rapid adaptation to the colder 
Table 2. Health of neonatal calves reared in warm and cold environments

\begin{tabular}{|c|c|c|c|c|c|c|c|}
\hline Health parameter/treatment & \multicolumn{7}{|c|}{ Period } \\
\hline \multicolumn{8}{|l|}{ Mean respiratory score ${ }^{1}$} \\
\hline Cold environment & 0.86 & 2.43 & 2.57 & 1.71 & 1.86 & 2.00 & 0.00 \\
\hline Treatment effect, $P$-value & NS & NS & 0.05 & NS & NS & 0.05 & NS \\
\hline \multicolumn{8}{|c|}{ Mean electrolyte and antibiotic costs, ${ }^{1} \$$} \\
\hline Treatment effect, $P$-value & NS & NS & NS & 0.05 & NS & 0.05 & NS \\
\hline
\end{tabular}

${ }^{1}$ Values represent mean weekly (i.e., period) respiratory scores and combined electrolyte/antibiotic costs for calves housed in warm and cold environments. Respiratory scores $=1$ respiratory day for each day antibiotic given for respiratory infection.

NS: $P>0.05$.

environment. Coat thickening provides increased thermal insulation and effectively reduces the LCT and the required cold-induced thermogenesis during exposure to temperatures below the LCT (Young, 1988).

Lighting in warm and cold environments was comparable in terms of intensity and duration, excluding potential effects of photoperiod on metabolic and immunologic responses of the calves. Effects of photoperiod on growth and immune function in cattle have been reviewed recently (Collier et al., 2006).

\section{Calf Health and Growth Performance}

Scour scores, days scouring, and the amount of electrolytes administered were comparable for calves in warm and cold environments (data not shown). Average weekly respiratory scores and antibiotic costs, however, were affected by environmental temperature (Table $2)$. Respiratory scores of cold-environment calves were higher $(P<0.05)$ during wk 3 and wk 6 . Antibiotic costs for cold-environment calves were higher during wk $4(P<0.05)$ and wk 6 . By wk 7 , treatment differences with regard to respiratory scores and costs associated with electrolyte and antibiotic administrations were not different. Blom et al. (1984) observed an increased incidence of pneumonia in calves given a milk substitute, hay, and concentrates when the ambient temperature was below $10^{\circ} \mathrm{C}$ and relative humidity exceeded $85 \%$, suggesting that low temperature in conjunction with elevated humidity affects calf respiratory health. Anecdotal evidence from producers also supports a direct effect of cold stress on the incidence and severity of respiratory infections in preruminant calves. Wetting the fur of experimentally infected, cold-stressed mice inhibited clearance of bacteria from the lungs (Green and Kass, 1964).

Effects of environmental temperature on growth performance and starter consumption are shown in Figure
2. Body weights of calves assigned to cold and warm environments were not different at the beginning of the study (d 0) and averaged 45.6 and $45.4 \mathrm{~kg}$, respectively (Figure 2a). Although treatment effect $(P<0.71)$ and treatment $\times$ time interaction $(P<0.28)$ were not significant for BW, the time effect was significant $(P<$ $0.0001)$. For all calves, BW did not change $(P>0.05)$ during the first $14 \mathrm{~d}$ of the study; however, from $\mathrm{d} 14$ to 49 it increased $(P<0.05)$ progressively $(0.68 \mathrm{~kg} / \mathrm{d})$ achieving a maximum of $69.5 \mathrm{~kg}$ on $\mathrm{d} 49$. Although calf BW was unaffected by environmental temperature, cold-environment calves consumed more starter than warm-environment calves during wk 5, 6, and 7 of the study (Figure 2b). Taken together, these data suggest that the extra energy associated with increased intake of starter was necessary for cold-environment calves to maintain a growth rate comparable to that of the warm-environment calves.

A summary of the effects of environment on the energy requirements of young calves (NRC, 2001) indicates that the maintenance energy requirement from birth to 4 wk of age ranges from 1,735 to 1,969 kcal of ME/d for calves at $15^{\circ} \mathrm{C}$ compared with 1,969 to $2,437 \mathrm{kcal}$ of $\mathrm{ME} / \mathrm{d}$ for calves at $5^{\circ} \mathrm{C}$ (calculated for a calf weighing $45.35 \mathrm{~kg}$ ). Because temperatures in the cold environment averaged $5^{\circ} \mathrm{C}$ during the study, substantially below the LCT (Young, 1988), the cold-environment calves likely required increased metabolic heat production to compensate for the increased thermal demand imposed by the cold environment. The energy requirement of cold-environment calves may have been even higher because of the regular wetting of their coats. The extra starter consumed by cold-environment calves was necessary to meet the increased $\mathrm{ME}$ requirement at $5^{\circ} \mathrm{C}$. For cold-environment calves fed only MR, an intensified MR with a higher fat percentage might provide the additional energy needed to meet the ME requirement when temperatures decreased below the LCT. 

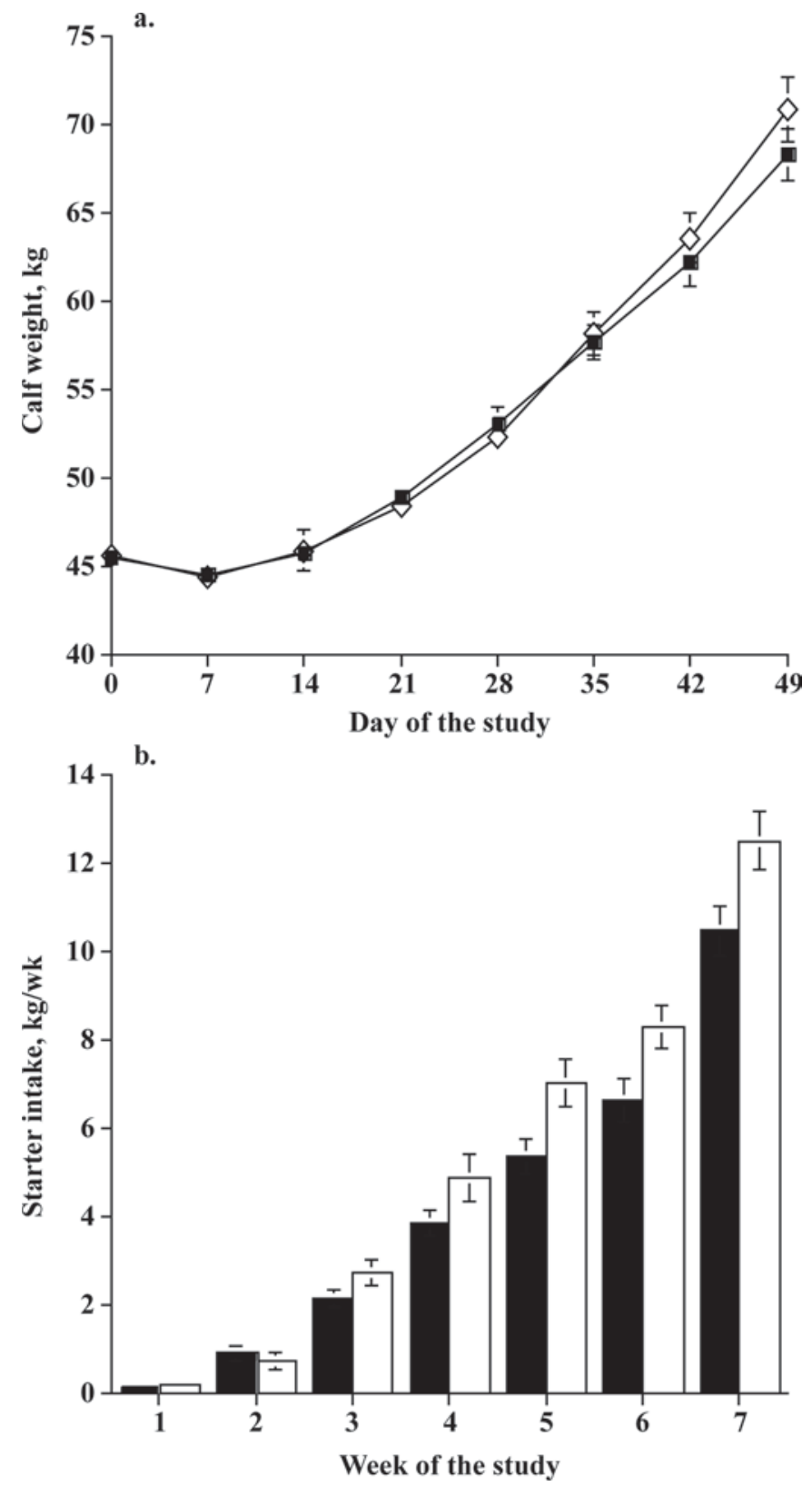

Figure 2. Growth performance (a) and starter intake (b) of preruminant calves housed in warm and cold environments. Growth performance is represented by mean $( \pm \mathrm{SEM}) \mathrm{BW}(\mathrm{kg})$ recorded at the beginning of the study and weekly thereafter for calves in warm $(\mathrm{n}=$ $15, \mathbf{\square})$ and cold $(\mathrm{n}=14, \diamond)$ environments. Starter intake is represented by the mean $( \pm$ SEM) weight of starter consumed each wk $(\mathrm{kg} / \mathrm{wk})$ of the study by calves in warm $(\mathrm{n}=15$, black bars $)$ and cold $(\mathrm{n}=14$, white bars) environments. Treatment effect, time effect, and treatment $\times$ time interaction for BW data were $P=0.71, P<0.0001$, and $P=$ 0.28 , respectively. For starter intake data, treatment effect, time effect, and treatment $\times$ time interaction for starter intake were $P=0.033, P$ $<0.0001$, and $P<0.0001$, respectively.
All calves in the present study were provided warm water 2 to 3 times a day. Observations by Kertz et al. (1984) suggest that availability of free water stimulates starter intake, helping to counteract cold stress.

\section{Concentrations of Glucose, NEFA, and Fat-Soluble Vitamins}

Glucose and NEFA concentrations in the circulation of calves housed in warm and cold environments are shown in Figure 3. It is generally accepted that blood glucose concentrations in young calves exceed adult values during the first weeks after birth but decrease to adult values (45-55 mg/dL) by $3 \mathrm{mo}$ of age. Blood glucose concentrations in calves raised in warm $(75.3$ $\mathrm{mg} / \mathrm{dL})$ and cold $(76.7 \mathrm{ng} / \mathrm{mL})$ environments were comparable at the beginning of the study (Figure 3a) and were higher than adult values. Glucose concentrations in cold-environment calves tended to be lower $(P$ $=0.06)$ than those in warm-environment calves (85.1 vs. $93.5 \mathrm{mg} / \mathrm{dL}$ ) during the study period. The treatment $\times$ time interaction was not significant $(P>0.05)$; however, glucose concentrations in warm-environment calves tended to be higher $(P=0.07)$ than those in cold-environment calves (103 vs. $89 \mathrm{mg} / \mathrm{dL} ; P=0.08$ ) on $\mathrm{d}$ 42. Blood glucose levels in all calves increased with time; however, this effect was more pronounced in warm-environment calves $(P<0.01)$ than in coldenvironment calves $(P=0.07)$.

Blood NEFA concentrations in both groups were not different $(P=0.99)$ at the beginning of the study ( $\mathrm{d} 0$; Figure $3 \mathrm{~b})$. All calves experienced a marked decrease in NEFA concentrations from d 0 through d 49. Coldenvironment calves had higher blood NEFA concentrations than warm-environment calves at d $35(P<0.001)$ and $\mathrm{d} 42(P<0.01)$. By d 49 , NEFA concentrations in both groups of calves were not different $(P=0.56)$. Because both groups showed a significant increase in blood glucose levels and parallel decreases in NEFA concentrations, it is likely that the cold-environment calves were not in a state of negative energy balance on d 35 or d 42. The NEFA values for cold-environment calves at d 35 to 49 were below threshold concentrations considered indicative of prepartum negative energy balance in dairy cows (Oetzel, 2004).

The fat-soluble vitamins A, E, and D are essential micronutrients in the diet of dairy cattle and necessary for optimal growth and immune function in the newborn calf. Plasma retinol, $R R R$ - $\alpha$-tocopherol, and $25-(\mathrm{OH}) \mathrm{D}_{3}$ concentrations in preruminant calves housed in warm and cold environments are shown in Figure 4, panels a, b, and c. Treatment effects and treatment $\times$ time interactions were not significant $(P$ $>0.05)$ for these vitamins, indicating that sustained 
exposure to cold did not influence fat-soluble vitamin status. When considering all calves, mean retinol concentrations increased $(P<0.0001)$ from a minimum of $109.7 \mathrm{ng} / \mathrm{mL}$ on d 0 to a maximum of $205.7 \mathrm{ng} / \mathrm{mL}$ on d 49. Vitamin D concentration increased modestly from $30.1 \mathrm{ng} / \mathrm{mL}$ on d 0 to $36.2 \mathrm{ng} / \mathrm{mL}$ on d $35(P<0.01)$, $38.0 \mathrm{ng} / \mathrm{mL}$ on d $42(P<0.001)$, and $37.0 \mathrm{ng} / \mathrm{mL}$ on d $49(P<0.01)$. The increases in plasma retinol and $25-(\mathrm{OH}) \mathrm{D}_{3}$ concentrations are typical of those observed in calves fed MR containing a minimum of 20,000 IU of vitamin A (Nonnecke et al., 1999) and 5,000 IU of vitamin D (B. Nonnecke; unpublished data) per pound of dry matter. Plasma tocopherol concentrations in all calves decreased $(P<0.001)$ from a maximum of $525 \mathrm{ng} / \mathrm{mL}$ on d 0 to a minimum of $310 \mathrm{ng} / \mathrm{mL}$ on d 49. Reasons for this unexpected decline are not known. Calves supplemented with vitamin $\mathrm{E}$ at levels comparable to the level provided in the present study typically undergo a pronounced age-related increase in plasma vitamin E concentrations (Nonnecke et al., 1999; Ametaj et al., 2000). Because of the known role of vitamin $\mathrm{E}$ in ensuring optimal function of the immune system, it is conceivable that both groups of calves may have experienced more health-related issues than calves with normal plasma vitamin E concentrations.

\section{Concentrations of Ovalbumin-Specific IgG, TNF- $\alpha$, and Haptoglobin}

Stress is known to influence both adaptive and innate immune responses in both young and adult animals. Because calves are vaccinated at a very early age, it is important to determine the effects of environmental stress on vaccine efficacy in the preruminant calf. Antibody (i.e., OVA-specific $\operatorname{IgG}_{1}$ ) responses of warm and cold environment calves to vaccination with OVA on $\mathrm{d}$ 0 and d 35 are shown in Figure 5a. Sensitization with OVA, an antigen not seen in the natural environment of the dairy cow, precluded the possibility that colostral antibody would negatively affect B-cell responses of calves to vaccination. Ovalbumin has been used successfully to evaluate B-cell function in the neonatal calf (Foote et al., 2007a). Treatment effect and treatment $\times$ time interaction were not significant for this variable, indicating that moderate cold exposure did not affect the adaptive (i.e., antigen-specific) immune response. All calves responded to primary vaccination, resulting in increased $(P<0.0001)$ antibody levels by d 35 . Responses at d 42 and d 49 exceeded $(P<0.001)$ those at $d 35$, suggesting that the second (i.e., booster) vaccination on d 35 induced an anamnestic or secondary response. Ovalbumin-specific $\operatorname{IgG}_{2}$ responses, although lower in magnitude, followed a similar pattern and were not affected by treatments (data not shown).
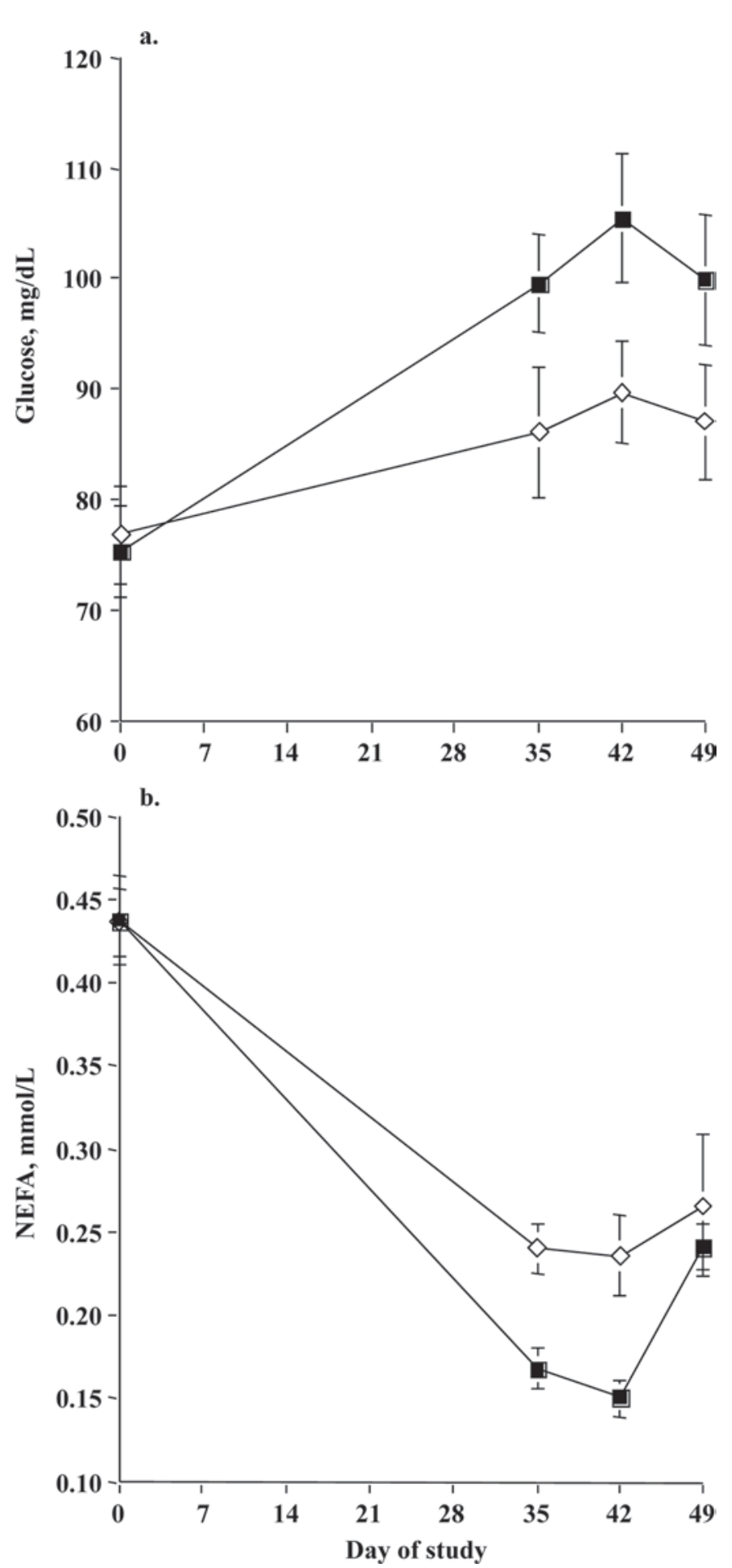

Figure 3. Glucose $(\mathrm{mg} / \mathrm{dL})$ and NEFA (mmol/L) concentrations (mean $\pm \mathrm{SEM}$ ) in peripheral blood from preruminant calves housed in warm $(\mathrm{n}=15, \boldsymbol{\square})$ and cold $(\mathrm{n}=14, \diamond)$ environments. Analyses were performed on samples collected on d $0,35,42$, and 49 of the study. Treatment effect, time effect, and treatment $\times$ time effect for the glucose data were $P=0.02, P<0.001$, and $P=0.31$, respectively. For the NEFA data, treatment effect, time effect, and treatment $\times$ time interaction were $P=0.05, P<0.0001$, and $P=0.08$, respectively. 


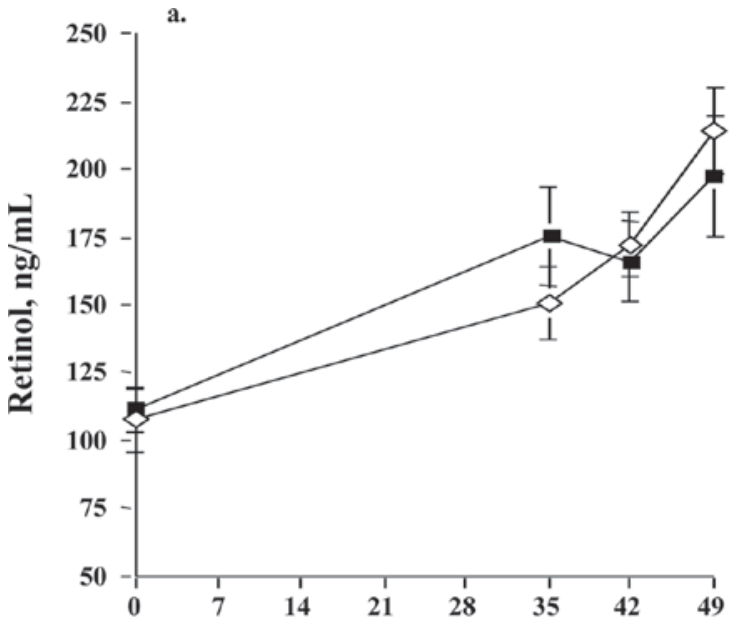

b.
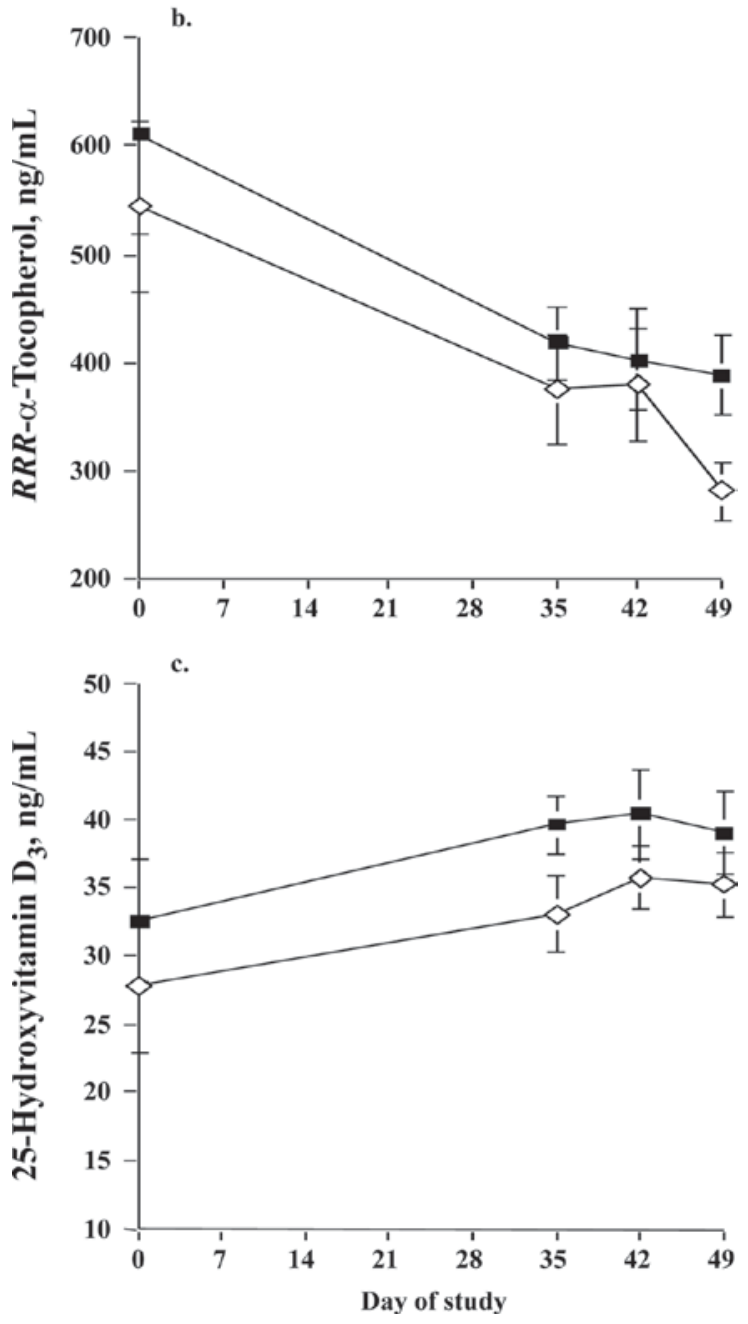

Figure 4. Vitamin A (retinol, $\mathrm{ng} / \mathrm{mL})$, vitamin $\mathrm{E}(R R R-\alpha-$ tocopherol, $\mathrm{ng} / \mathrm{mL}$ ), and vitamin $\mathrm{D}\left(25-\mathrm{OH}\right.$-vitamin $\left.\mathrm{D}_{3}, \mathrm{ng} / \mathrm{mL}\right)$ concentrations (mean \pm SEM) in peripheral blood from calves housed in warm $(\mathrm{n}=15, \mathbf{\square})$ and cold $(\mathrm{n}=14, \diamond)$ environments. Analyses were performed on samples collected at d 0, 35, 42, and 49 of the study. Treatment effects and treatment $\times$ time interactions were not significant for retinol, vitamin $\mathrm{E}$, or vitamin D. However, time effects were significant for each variable $(P<0.01$ for all variables $)$.

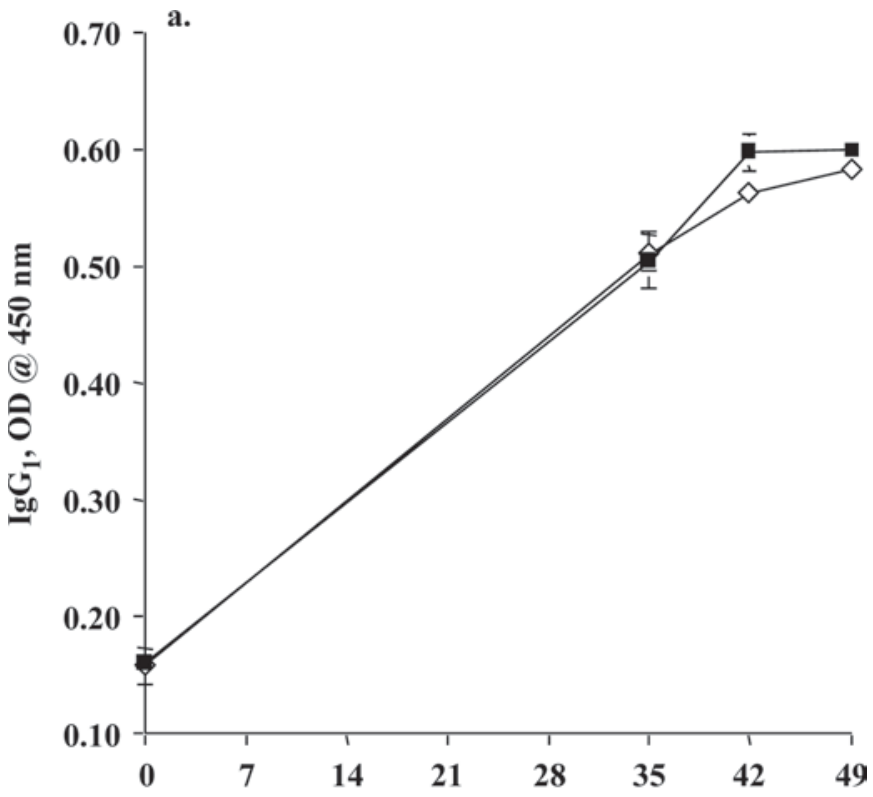

b.

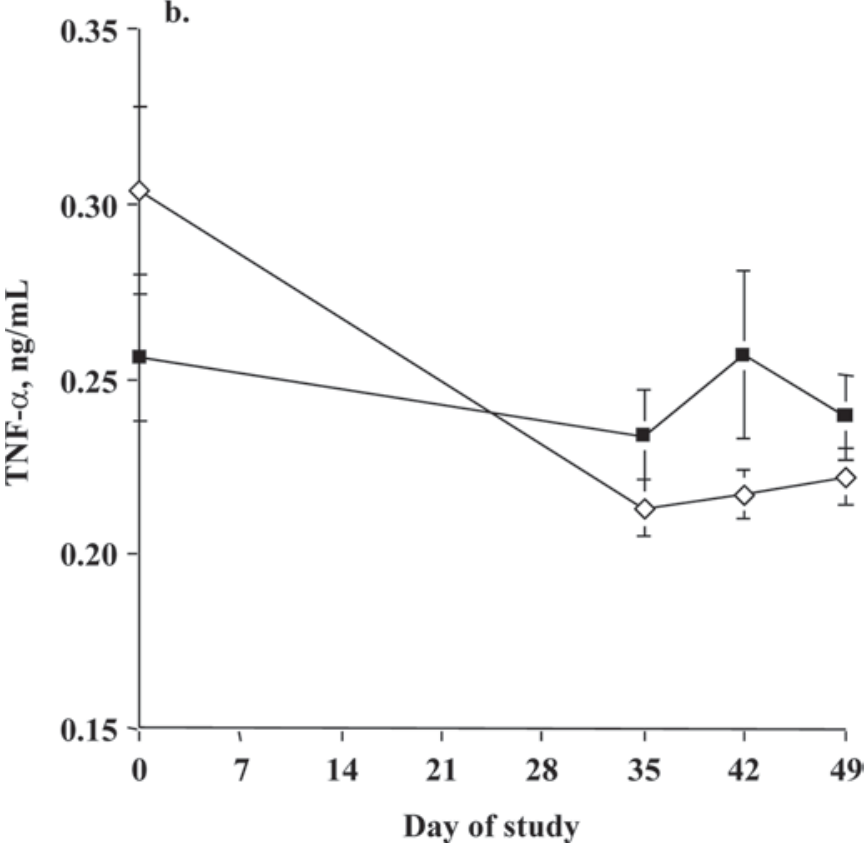

Figure 5. Ovalbumin (OVA)-specific IgG $\mathrm{Ig}_{1}$ (optical density (OD) at $450 \mathrm{~nm}$, panel a] and tumor necrosis factor (TNF)- $\alpha(\mathrm{ng} / \mathrm{mL}$, panel b) in peripheral blood from calves housed in warm $(\mathrm{n}=13, \mathbf{\square})$ and cold $(\mathrm{n}=18, \diamond)$ environments. All calves were vaccinated subcutaneously in the left mid-cervical region with OVA in incomplete Freund's adjuvant on $\mathrm{d} 0$ and 35 . Analyses were performed on samples collected at $\mathrm{d} 0,35,42$, and 49 of the study. Analysis of OVA-specific $\operatorname{IgG}_{1}$ data indicated that the treatment effect, time effect, and treatment $\times$ time interaction were $P=0.35, P<0.0001$, and $P=0.42$, respectively. For the TNF- $\alpha$ data, treatment effect, time effect, and treatment $x$ time interaction were $P=0.64, P<0.0001$, and $P<0.10$, respectively. 
Table 3. Serum haptoglobin concentrations $(\mu \mathrm{g} / \mathrm{mL}$; mean \pm SEM) in blood samples collected on d 0 , d 35, d 42 , and d 49 of the study

\begin{tabular}{llccc}
\hline & \multicolumn{4}{c}{ Day of study } \\
\cline { 2 - 5 } Treatment group & \multicolumn{1}{c}{ d 0} & d 35 & d 42 & d 49 \\
\hline Warm environment $(\mathrm{n}=15)$ & $2.36 \pm 1.48$ & $0.24 \pm 0.22$ & $2.37 \pm 1.72$ & $4.19 \pm 3.98$ \\
Cold environment $(\mathrm{n}=14)$ & $0.45 \pm 0.345$ & $8.78 \pm 6.05$ & $5.51 \pm 3.77$ & $2.30 \pm 2.22$ \\
\hline
\end{tabular}

Tumor necrosis factor- $\alpha$, produced by monocytes and macrophages, is a key mediator of the inflammatory response and it promotes T- and B-lymphocyte proliferation. Blood TNF- $\alpha$ concentration is frequently elevated during acute and chronic inflammation associated with the body's response to infection and is considered a marker for immune activation. Cytokine concentrations in sera from warm- and cold-environment calves are shown in Figure 5b. Although TNF- $\alpha$ concentrations in warm-environment calves did not change during the study period, levels in cold-environment calves were lower $(P<0.0001)$ on $\mathrm{d} 35,42$, and 49 than at the beginning of the study. Blood TNF- $\alpha$ levels in warm- and cold-environment calves, however, were not different $(P$ $>0.05)$ at any sampling time during the 7 -wk trial, suggesting that the level of immune activation in both groups of calves was comparable. The significant time effect, characterized by lower $(P<0.001)$ TNF- $\alpha$ levels in all calves on wk 5, 6, and 7 compared with wk 0 , may reflect to some degree immunological adaptation of the rapidly developing calf to pathogen exposure during the first months of life.

Haptoglobin is one of several acute phase proteins produced in response to inflammatory changes associated with infection, making it a potentially useful indicator of calf health. Previous research indicates that serum haptoglobin levels range from very low to undetectable in healthy calves to $>1 \mathrm{mg} / \mathrm{mL}$ during Mannheimia hemolytica-induced respiratory disease (Godson et al., 1996). The study demonstrated that haptoglobin concentrations are highly correlated with sick score (subjective clinical examination), body temperature, weight change, and plasma zinc concentration. Experimental infection of calves with bovine respiratory syncytial virus also results in marked induction of haptoglobin, IL-6, and IFN- $\gamma$ mRNA (Grell et al., 2005). Serum haptoglobin concentrations in warm- and cold-environment calves are presented in Table 3 . Treatment $(P=0.47)$ and time $(P=0.52)$ effects as well as a treatment $\times$ time interaction $(P=0.16)$ were not significant for this variable, suggesting that the level of immune activation in warm- and cold-environment calves was comparable. There was a trend $(P=0.08)$ toward increased haptoglobin concentrations in cold-environment calves between $\mathrm{d} 0$ and 35 . In contrast, changes in haptoglobin concentrations in warm-environment calves during the same period were negligible $(P=0.45)$. Haptoglobin concentrations $(<10 \mu \mathrm{g} / \mathrm{mL})$ in the serum of calves in the present study were substantially lower than those (>3 mg/mL) observed $4 \mathrm{~d}$ after experimental infection with Mannheimia hemolytica, suggesting that both warm- and cold-environment calves in this study were relatively healthy.

In conclusion, the results from the present study indicate that preruminant calves provided adequate nutrition exhibit a remarkable degree of adaptability to sustained, moderate cold. When compared with warm-environment calves, cold-environment calves had similar growth rates likely maintained by their increased intake of starter grain. Immune response variables also were unaffected by cold. With the exception of a moderate increase in respiratory scores, the health of cold-stressed calves was comparable to that of warm-environment calves. These results suggest that successful adaptation of the dairy calf to sustained cold may be linked to the availability of adequate nutrition. Because this study considered the effects of moderate cold stress, additional research is needed to evaluate effects of sustained, severe cold on limit-fed calves (i.e., calves fed no more than warm-environment calves).

\section{ACKNOWLEDGMENTS}

The authors thank B. Perry and T. Martin of Land O'Lakes Inc. (Webster, IA) for their support during the animal component of the study and D. McDorman, N. Eischen, D. Hoy, and A. Hall from the National Animal Disease Center (Ames, IA) for technical support.

\section{REFERENCES}

Ametaj, B. N., B. J. Nonnecke, S. T. Franklin, R. L. Horst, W. R. Bidlack, R. L. Stuart, and D. C. Beitz. 2000. Dietary vitamin A modulates the concentration of RRR- $\alpha$-tocopherol in plasma lipoproteins from calves fed milk replacer. J. Nutr. 130:629-636.

Aviles, H., M. T. Johnson, and F. P. Monroy. 2004. Effects of cold stress on spleen cell proliferation and cytokine production during chronic Toxoplasma gondii infection. Neuroimmunodulation 11:93-102.

Blom, J. Y. I. Thysen, V. Ostergaard, and F. Moller. 1984. Calf health and weight gain in relation to stall climate, iron and immune status and disease treatment. Beretn. Statens Husdyrbrugsfors $\varnothing \mathrm{g}$ 570:108-112. 
Collier, R. J., G. E. Dahl, and M. J. Van Baale. 2006. Major advances associated with environmental effects on dairy cattle. J. Dairy Sci. 89:1244-1253.

Drackley, J. K. 2005. Early growth effects on subsequent health and performance of dairy calves. Pages 213-236 in Calf and Heifer Rearing-Principles of Rearing the Modern Dairy Heifer from Calf to Calving. Nottingham University Press, Nottingham, UK.

Foote, M. R., B. J. Nonnecke, D. C. Beitz, and W. R. Waters. 2007a. Antigen-specific B-cell responses by neonatal calves after early vaccination. J. Dairy Sci. 90:5208-5217.

Foote, M. R., B. J. Nonnecke, D. C. Beitz, and W. R. Waters. 2007b. High growth rate fails to enhance adaptive immune responses of neonatal calves and is associated with reduced lymphocyte viability. J. Dairy Sci. 90:404-417.

Frank, J. W., J. A. Carroll, G. L. Allee, and M. E. Zanelli. 2003. The effects of thermal environment and spray-dried plasma on the acute-phase response of pigs challenged with lipopolysaccharide. J. Anim. Sci. 81:1166-1176.

Godden, S. M., J. P. Fetrow, J. M. Feirtag, L. R. Green, and S. J. Wells. 2005. Economic analysis of feeding pasteurized nonsaleable milk versus conventional milk replacer to dairy calves. J. Am. Vet. Med. Assoc. 226:1547-1554.

Godson, D. L., M. Campos, S. K. Attah-Poku, M. J. Redmond, D. M. Cordeiro, M. S. Sethi, R. J. Harland, and L. A. Babuik. 1996. Serum haptoglobin as an indicator of the acute phase response in bovine respiratory disease. Vet. Immunol. Immunopathol. $51: 277-292$.

Green, G. M., and E. H. Kass. 1964. Factors influencing the clearance of bacteria by the lung. J. Clin. Invest. 43:769-776.

Grell, S. N., K. Tjornehoj, L. E. Larsen, and P. M. H. Heegard. 2005. Marked induction of IL-6, haptoglobin and IFN-g following experimental BRSV infection in young calves. Vet. Immunol. Immunopathol. 103:235-245.

Hangalapura, B. N., M. G. Kaiser, J. J. Poel, H. K. Parmentier, and S. J. Lamont. 2005. Cold stress equally enhances in vivo proinflammatory cytokine gene expression in chicken lines divergently selected for antibody responses. Dev. Comp. Immunol. 30:503511.

Hollis, B. W., J. Q. Kamerud, S. R. Selvaag, J. D. Lorenz, and J. L. Napoli. 1993. Determination of vitamin D status by radioimmunoassay with a ${ }^{125}$-labeled tracer. Clin. Chem. 39:529533.

Johnson, M. M., and J. P. Peters. 1993. Technical note: An improved method to quantify nonesterified fatty acids in bovine plasma. J. Anim. Sci. 71:753-756.

Kaplan, L. A., J. A. Miller, and E. A. Stein. 1987. Simultaneous measurement of serum retinol, tocopherols, carotenes, and carotenoids by high performance liquid chromatography. J. Clin. Lab. Anal. 1:147-152.
Kertz, A. F., L. F. Reutzel, and J. H. Mahoney. 1984. Ad libitum water intake by neonatal calves and its relationship to calf starter intake, weight gain, and season. J. Dairy Sci. 76:2964-2969.

Lago, A., S. M. McGuirk, T. B. Bennett, N. B. Cook, and K. V. Nordlund. 2006. Calf respiratory disease and pen microenvironments in naturally ventilated calf barns in winter. J. Dairy Sci. 89:40144025 .

Martin, S. W., C. W. Schwabe, and C. E. Franti. 1975. Dairy calf mortality rate: influence of meterologic factors on calf mortality in Tulare County, California. Am. J. Vet. Res. 36:1105-1109.

National Animal Health Monitoring Service. 2002. United States Department of Agriculture, Animal Plant and Health Inspection Service. Veterinary Services. Part 1: Reference of the Dairy Health and Management in United States. USDA, Washington, DC.

Nonnecke, B. J., M. R. Foote, J. M. Smith, B. A. Pesch, and M. E. Van Amburgh. 2003. Composition and functional capacity of blood mononuclear leukocyte populations from neonatal calves on standard and intensified milk replacer diets. J. Dairy Sci. 86:3592-3604.

Nonnecke, B. J., R. L. Horst, W. R. Waters, P. Dubeski, and J. A. Harp. 1999. Modulation of fat-soluble vitamin concentrations and blood mononuclear leukocyte populations in milk replacerfed calves by dietary vitamin A and $\beta$-carotene. J. Dairy Sci 82:2632-2641.

Nonnecke, B. J., W. R. Waters, M. R. Foote, M. V. Palmer, B. L. Miller, T. E. Johnson, H. B. Perry, and M. A. Fowler. 2005. Development of adult-like cell-mediated immune response in calves after early vaccination with Mycobacterium bovis bacillus Calmette-Guerin. J. Dairy Sci. 88:195-210.

NRC. 2001. Nutrient Requirements of Dairy Cattle. 7th rev. ed. National Academy of Science Press, Washington, DC.

Oetzel, G. R. 2004. Monitoring and testing dairy herds for metabolic disease. Vet. Clin. Food Anim. 20:651-674.

Schrama, J. W., A. Arieli, W. van der Hel, and M. W. Verstegen. 1993. Evidence of increasing thermal requirement in young, unadapted calves during 6 to 11 days of age. J. Anim. Sci. 71:1761-1766.

Schrama, J. W., W. van der Hel, A. Arieli, and M. W. Verstegen. 1992. Alteration of energy metabolism of calves fed below maintenance during 6 to 14 days of age. J. Anim. Sci. 70:2527-2532.

Scibilia, L. S., L. D. Muller, R. S. Kensinger, T. F. Sweeney, and P. R. Shellenberger. 1987. Effect of environmental temperature and dietary fat on growth and physiological responses of newborn calves. J. Dairy Sci. 70:1426-1433.

Woodward, B. 1998. Protein, calories, and immune defenses. Nutr. Rev. 56:S84-S92.

Young, B. A. 1988. Effect of environmental stress on nutrient needs. Pages 456-467 in The Ruminant Animal Digestive Physiology and Nutrition. D. C. Church, ed. Prentice Hall, Englewood Cliffs, NJ. 